\title{
SKIRTINGŲ KRŪTIES VĖŽIO LĄSTELIŲ LINIJŲ ATSPARUMO RADIOTERAPIJAI TYRIMAS
}

\author{
Danguolė Laukaitiené $\dot{e}^{1}$, Antanas Vaitkus ${ }^{2}$, Aistė Savukaitytė ${ }^{1}$, Roberta Vadeikiené $\dot{1}^{1}$, \\ Arturas Inčiūra ${ }^{1}$, Rasa Ugenskiené $\dot{1}^{1}$, Elona Juozaitytè ${ }^{1}$ \\ ${ }^{1}$ Lietuvos sveikatos moksly universiteto Onkologijos institutas, \\ ${ }^{2}$ Lietuvos sveikatos moksly universiteto Radiologijos klinika
}

Raktažodžiai: krūties vėžys, atsparumas, radioterapija, apoptozè, ląstelès ciklas.

\begin{abstract}
Santrauka
İvadas. Radioterapija yra vienas iš pagrindinių vėžio gydymo metodų, taikomų daugiau kaip pusei onkologiniu pacientu. Manoma, kad pagrindinè onkologinès ligos pasikartojimo ir nesėkmingo gydymo priežastis yra věžinių ląstelių atsparumas radioterapijai. Viena iš pagrindinių atsparumo radioterapijai priežasčių yra véžinių ląstelių gebejjimas išvengti apoptozès. Manoma, kad ląstelès ciklas taip pat yra vienas iš procesų, turinčių reikšmès radioatsparumui. Šio tyrimo tikslas - ịvertinti skirtingų krūties vėžio ląstelių linijų atsparumą radioterapijai, lyginant jų gyvybingumą, ląstelių pasiskirstymą tarp ciklo fazių ir apoptozès intensyvumą. Metodika. MCF-7 ir MDA-MB-231 ląstelių gyvybingumas buvo ištirtas, naudojant kolonijų formavimo testą. Ląstelès ciklo analizei buvo dažomos propidžio jodidu ir analizuojamos, naudojant tékmès citometrą Muse Cell Analyzer. Apoptozès intensyvumui nustatyti naudotas aneksinas V ir Guava PCA tékmès citometras. Rezultatai. Šiame tyrime nustatėme, kad MDAMB-231 ląsteliu gyvybingumas po radioterapijos poveikio buvo didesnis, nei MCF-7 ląstelių. Ciklo analizè parodé, kad po radioterapijos poveikio MCF-7 ląstelių ciklo sustabdymas vyko G0/G1 fazejje, o MDA-MB-231 ląstelių - G2/M fazejje. Po radioterapijos poveikio MCF-7 ląstelèse apoptozė prasidejjo anksčiau ir buvo intensyvesnè, o MDA-MB-231 ląstelès reagavo vèliau ir turèjo uždelstą apoptozini atsaką. Išvados. MDA-MB-231 ląstelès buvo atsparesnès radioterapijai, negu MCF-7 ląstelès.
\end{abstract}

\section{Ivadas}

Krūties vėžys yra dažniausia onkologinè moterų liga ne tik Lietuvoje, bet ir daugelyje išsivysčiusių pasaulio šalių. Vien per 2020 metus pasaulyje nustatyta apie 2,3 milijono naujų krūties vėžio atvejų. Nuo šio vėžio kasmet miršta daugiau kaip pusè milijono pacientų ir tai yra penkta pagal mirtingumą věžio forma. Šie skaičiai atspindi krūties věžio paplitimo dydį, prevencinių bei terapinių priemonių plètojimo poreiki [1].

Krūties vėžys yra labai heterogeniška liga, turinti platų klinikinių, patologinių bei molekulinių savybių spektrą ir klasifikuojama ị keletą biologinių potipių [2]. Ši klasifikacija paremta imunohistocheminiu tyrimu nustačius estrogenų (ER), progesteronų (PR), EGFR receptorių Her2 (HER2) ir Ki67 statusą věžio ląstelèse. Šie krūties vėžio potipiai pasižymi skirtingais rizikos veiksniais, naviko charakteristikomis bei atsaku i gydymą. Navikai, kuriuose nustatomi estrogenų ir progesteronų receptoriai yra susiję su geresne ligos prognoze ir geru atsaku į hormonų terapiją. Navikai su padidejusia HER2 raiška yra blogesnès prognozės, daug piktybiškesni ir juos reikia intensyviau gydyti. Blogiausia prognoze pasižymi trigubai neigiamas potipis, išsiskiriantis savo biologinèmis savybėmis, agresyviu augimu, metastazavimo savitumais ir dažnesniu ligos atkryčiu $[3,4]$. Šių potipių klasifikavimas yra didelis laimèjimas gydant krūties véžị ir tai yra pagrindas sisteminei terapijai parinkti. İrodyta, kad atsakas ị chemoterapiją priklauso nuo krūties véžio potipių, tačiau mažai žinoma apie jų atsaką i spindulini gydymą [5]. Manoma, kad radioterapijos poveikis skirtingiems ligos potipiams gali būti nevienodas ir siejamas su ląstelių radiojautrumo ir radioatsparumo savybèmis [6].

Radioterapija yra vienas iš pagrindinių kompleksinio vėžio gydymo metodų, taikomų daugiau kaip pusei onkologinių pacientų. Užkirsdama kelią lokaliam ligos atkryčiui, radioterapija padeda sumažinti tolimujų metastazių ir mirtingumo dažnị [7]. Nors radioterapija yra efektyvus krūties vėžio gydymo metodas, tačiau ne visiems pacientams veiksmingas. Ligos atsinaujinimas rodo nevisišką vėžio ląstelių išnaikinimą ir (ar) igytą atsparumą gydymui [8]. Nors su radioatsparumu susiję molekuliniai mechanizmai plačiai tyrinejjami, tačiau nèra galutinai suprasti [9].

Po jonizuojančiosios spinduliuotès poveikio ląstelès inte- 
gralumo palaikyme dalyvauja daug svarbių procesų. Vienas jų - ląstelès ciklo reguliacija, aktyvinanti DNR pažaidų patikros taškus. Kaip atsakas i i genotoksinius veiksnius, šie patikros taškai sustabdo ląstelès ciklą ir duoda laiko ląstelių reparacijai arba inicijuoja ląstelès mirti [10]. Radioterapijos tikslas - sukelti dvigubus DNR grandinès trūkius vėžinèse ląstelèse, nuslopinti pažaidų atitaisymo mechanizmus, siekiant paskatinti ląstelès ciklo sustabdymą ir apoptozę [6]. Manoma, kad vėžinès ląstelès gali turèti defektyvius ląstelès ciklo patikros taškus, kurie leidžia dalytis, išvengiant pažaidų atitaisymo. Taip vėžinès ląstelès gali išvengti apoptozès [11], o tai yra viena iš pagrindinių atsparumo radioterapijai priežasčių. Apoptozė yra labai svarbi fiziologinio balanso palaikymui tarp ląstelès augimo ir mirties. Dauguma priešvěžinių terapijų nukreipta ị apoptozę ir su ja susijusius signalinius kelius piktybinių ląstelių pašalinimui [12]. Veežinès ląstelès dažnai geba išvengti mirtį sukeliančios apoptozès dèl išsireguliavusių apoptoziniu signalų, tokių kaip antiapoptozinès sistemos aktyvacija, kaspazių ir jų inhibitorių funkcijų sutrikimo, mirties receptorių signalų susilpnejjimo, p53 geno mutacijų ir kt. [13]. Toks véžio ląstelių apoptozès išvengimas gali sukelti nekontroliuojamą proliferaciją, skatinti naviko išgyvenimą, iggyant atsparumą ar sukeliant ligos atsinaujinimą [12].

Tyrimo tikslas - įvertinti skirtingų krūties vėžio ląstelių linijų atsparumą radioterapijai, lyginant jų gyvybingumą, ląstelių pasiskirstymą tarp ciklo fazių ir apoptozès intensyvumą.

\section{Tyrimo medžiaga ir metodai}

Ląstelių linijos ir auginimo sąlygos. MCF-7 ir MDAMB-231 krūties vėžio ląstelès buvo nupirktos iš CLS Cell Line Service (Vokietija). Visos ląstelès buvo auginamos DMEM (Dulbecco's Modified Eagle's Medium, Sigma-Aldrich) augimo terpeje, papildytoje $10 \%$ fetaliniu jaučio serumu ( $F B S$, Gibco), 1\% L-glutaminu (Gibco) ir $100 \mathrm{IU} / \mathrm{ml}$ penicilinostreptomicino antibiotiku (Gibco). Ląstelès auginamos $25 \mathrm{~cm}^{2}$ flakonèliuose su $5 \mathrm{ml}$ augimo terpès ir laikomos inkubatoriuje, kuriame palaikoma reikalinga $37{ }^{\circ} \mathrm{C}$ temperatūra, drègnumas ir 5\% $\mathrm{CO}_{2}$ prisotinta aplinka. Ląsteliu atkèlimui buvo naudojamas tripsino/EDTA tirpalas (Gibco).

Koloniju formavimo testas. MCF-7 ir MDA-MB-231 krūties véžio ląstelès buvo pasètos skirtingais kiekiais ị 6 šulinèlių lëkšteles ir paliktos per naktį, kad prisitvirtintų prie lèkštelès dugno. Po to ląstelès buvo apšvitintos 2, 4, 6, 8 ir 10 Gy jonizuojančiosios $6 \mathrm{MV}$ fotoninès spinduliuotès dozèmis, naudojant spindulinès terapijos linijini greitintuvą Clinac $2100 C / D$. Kontrolinès grupès ląstelès buvo nešvitintos. Visos lèkštelès su ląstelèmis buvo laikomos dvi savaites $37^{\circ} \mathrm{C}$ temperatūroje. Susiformavusios kolonijos buvo fiksuojamos $96 \%$ etanoliu, dažomos $1 \%$ kristalo violeto (Merck KGaA, Vokietija) dažais, plaunamos vandeniu ir išdžiovinamos. Kolonijos skaičiuojamos naudojant šviesinį mikroskopą. Tikra kolonija laikoma tokia, kuri susideda iš mažiausiai 50 ląstelių. Ląstelių išgyvenamumas apskaičiuotas dalijant kolonijų skaičiu iš pasètų ląstelių skaičiaus ir dauginant iš sẻjimo efektyvumo. Iš viso buvo atlikti trys nepriklausomi eksperimentai.

Ląstelès ciklo analizè. MCF-7 ir MDA-MB-231 krūties vėžio ląstelès buvo pasètos i 6 šulinèlių lèkšteles. Po 24 val. ląstelès buvo apšvitintos 2, 4, 6, 8 ir 10 Gy jonizuojančiosios spinduliuotès dozèmis ir inkubuotos 24, 48 ir 72 valandas. Kontrolinès ląstelių grupès buvo nešvitintos. Atkeltos ląstelès dukart plaunamos su 1xPBS ir fiksuojamos 70\% lediniame etanolyje. Laikomos per naktį $-20^{\circ} \mathrm{C}$ temperatūroje. Toliau vèl plaunamos su 1xPBS ir dažomos propidžio jodidu, naudojant Muse Cell Cycle Kit rinkinị. Ląstelès ciklo pasiskirstymas buvo analizuojamas tékmès citometru Muse Cell Analyzer (Millipore, Billerica, MA, USA).

Apoptozès analizè. MCF-7 ir MDA-MB-231 krūties vèžio ląstelès buvo pasètos i $25 \mathrm{~cm}^{2}$ flakonèlius ir po 24 val. apšvitinamos 2, 4, 6, 8 ir 10 Gy jonizuojančiosios spinduliuotès dozèmis. Kontrolinės grupès ląstelès nešvitintos. Po radioterapijos poveikio praejjus 24,48 ir 72 val., ląstelès buvo pakeltos nuo lèkštelès dugno ir dažomos aneksinu V, naudojant Flow Cellect MitoDamage Kit reagentų rinkinį. Apoptozès intensyvumui nustatyti buvo naudotas tèkmès citometras Guava PCA.

Statistinè duomenų analizė. Visi eksperimentai pakartoti mažiausiai 3 kartus. Statistinè duomenų analizė atlikta naudojant SPSS 20 (IBM SPSS Inc., Chicago, IL) programą, taikant Student $t$ kriterijų. Kai reikšmingumo lygmuo $p<0,05$, tuomet skirtumas tarp dviejų imčių ar jų grupių laikytas statistiškai reikšmingu.

\section{Tyrimo rezultatai}

Kolonijų formavimo testas. Po radioterapijos poveikio MCF-7 ir MDA-MB-231 ląstelių gyvybingumui palyginti buvo pasirinktas kolonijų formavimo testas. Mūsų rezultatai parodè, kad po poveikio 2 Gy doze abiejų linijų ląsteliu gyvybingumas ženkliai sumažejo: MCF-7 ląstelių 45,84\% $\pm 2,24$, o MDA-MB- $231-51,9 \% \pm 2,27$. Po 4 Gy dozès kolonijas formavo tik $8,76 \% \pm 2,43 \mathrm{MCF}-7$ linijos ląsteliu, o MDA-MB-231 - 22,27\% $\pm 7,22$. Reikšmingas skirtumas tarp linijų buvo ir po 6 Gy dozès: $1,53 \% \pm 1,2$ ir $9,42 \% \pm 5,48$ atitinkamai MCF-7 ir MDA-MB-231. Po 8 ir 10 Gy MCF-7 ląstelès beveik visai neformavo kolonijų (atitinkamai $0,23 \%$ $\pm 0,19 ; 0,01 \% \pm 0,026$ ), buvo randama viena kolonija arba visai nerandama. MDA-MB-231 linijos ląstelès po 8 Gy dozès kolonijas formavo $2,64 \% \pm 0,66$ ląsteliu, o po $10 \mathrm{~Gy}$ buvo randama iki 4 kolonijų lèkštelèje $(0,47 \% \pm 0,4)$. Remiantis gautais duomenimis, galima teigti, kad MDA-MB-231 ląstelès buvo atsparesnès radioterapijos poveikiui nei MCF-7 ląstelès (1 pav.). 
Ląstelès ciklo analizė. Atlikome MCF-7 ir MDA-MB-231 ląstelių ciklo analizę po radioterapijos poveikio. Kaip rodo mūsų rezultatai, po 24 val. MCF-7 ląstelès liko G0/G1 fazèje ir reikšmingai nekito, didejjant radioterapijos dozėms. $\mathrm{S}$ fazèje matomas ląstelių sumažẻimas didejjant spindulinès terapijos dozėms, o G2/M fazèje nežymus padejjimas tik esant 8 ir $10 \mathrm{~Gy}$. Po 48 valandų nustatytas nežymus ląstelių kiekio didejjimas G0/G1 fazèje, o po 72 val. pastebètas grịžimas prie 24 val. poveikio reikšmių ( 2 pav.). Panaši tendencija nustatyta ir kitose ciklo fazėse, kai praejus 72 valandoms, ląstelių ciklas normalizuojasi. Manoma, kad po radioterapijos poveikio MCF-7 ląstelių ciklas galèjo būti laikinai sustabdytas G0/G1 fazeje ir po 72 val. grižti ị normalų ląstelès ciklą. Visiškai kitokius rezultatus parodè MDA-MB-231 ląstelių ciklo analizè, praèjus 24 valandoms po radioterapijos poveikio. Kaip matyti 3 pav., 4, 6, 8 ir 10 Gy dozès poveikio taškuose ląstelių kiekiai sumažèjo G0/G1 ir žymiai padidèjo G2/M

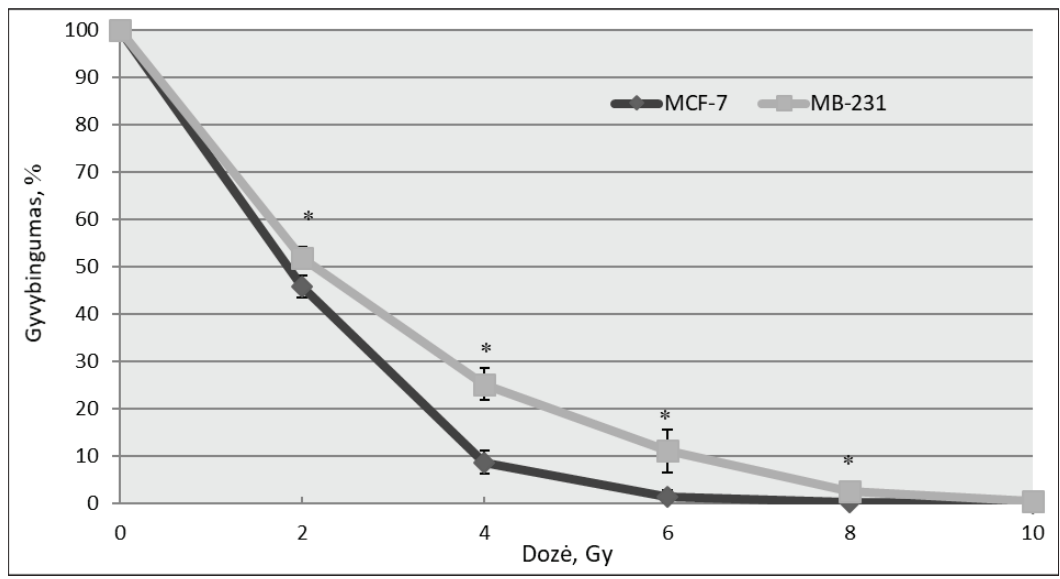

1 pav. MDA-MB-231 ir MCF-7 krūties vėžio ląstelių linijų gyvybingumo priklausomybè nuo radioterapijos dozių

Kiekvienas taškas yra trijų nepriklausomu eksperimentu vidurkis su standartiniu nuokrypiu. Žvaigždutè (*) rodo statistiškai reikšminga vertę, lyginant tarp ląsteliu liniju.

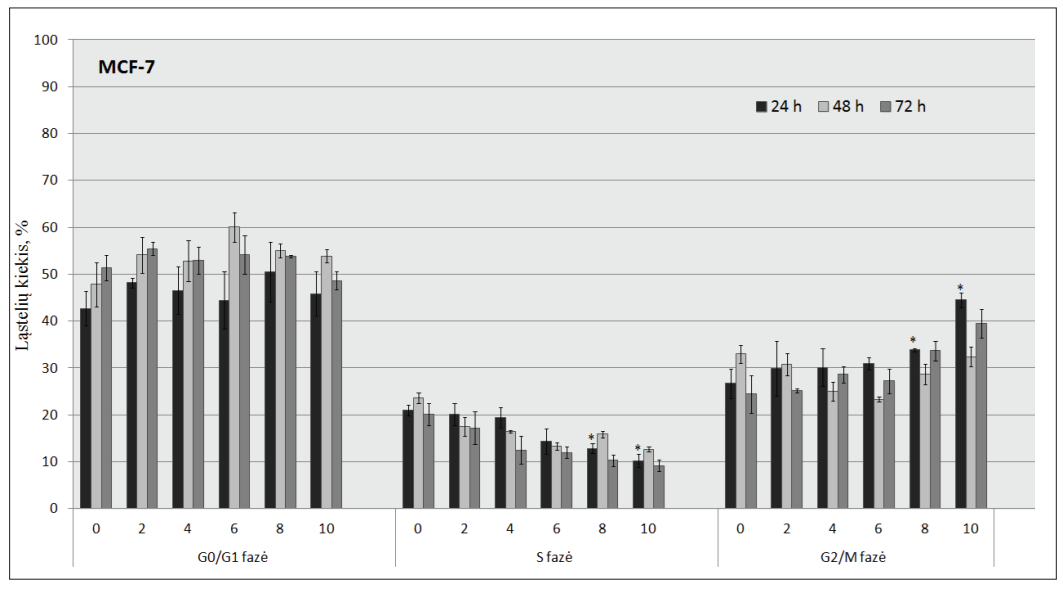

2 pav. MCF-7 ląstelių pasiskirstymas tarp ciklo fazių po 0,2 , 4, 6, 8, 10 Gy dozių radioterapijos poveikio

Kiekvienas taškas yra triju nepriklausomu eksperimentu vidurkis su standartiniu nuokrypiu. Žvaigždutè (*) rodo statistiškai reikšminga vertę, lyginant su kontroline. fazèje, tačiau jau po 48 val. stebimas ląstelių sugrị̌žimas ị savo pradinę ciklo būseną, t.y. ląstelių kiekiai radioterapijos paveiktose grupèse artejja prie kontrolinių grupių reikšmių, kai G0/G1 fazèje ląstelių kiekiai didèja, o G2/M - mažèja. Tą patvirtina ir rezultatai, gauti po 72 valandu poveikio, nes jų reikšmès labai priartèja prie kontrolinès grupes reikšmių. Vadinasi, po radioterapijos poveikio MDA-MB-231 ląstelių ciklas buvo laikinai sustabdytas G2/M fazėje. Literatūroje sutinkama duomenų, kad kuo didesnè jonizuojančiosios spinduliuotès dozè, tuo ilgiau gali užtrukti ląstelès ciklo sustabdymas [14]. Tai atsispindi ir mūsų rezultatuose, kad po poveikio 2, 4, 6 Gy dozèmis ląstelèms reikèjo 48 valandų, o po poveikio 8 ir 10 Gy -72 valandų sugrįžti ị normalų ląstelès ciklą. MCF-7 ląstelèms taikytos radioterapijos dozès neturèjo reikšmès laikui, kurio reikejjo ląstelių ciklo normalizavimuisi.

Apoptozès analizė. Buvo atlikti apoptozès tyrimai, siekiant išsiaiškinti, ar mūsų tiriamų ląstelių atsakas ị radioterapiją skirsis, vertinant ląstelių apoptozés intensyvumą. Mūsų rezultatai rodo, kad jau po 24 val. MCF-7 linijos apoptozinių ląstelių buvo po 8 ir 10 Gy dozių, o MDA-MB-231 ląstelès neparode apoptozinio atsako i jonizuojančiają spinduliuotę: nei prie vienos taikytos dozès apoptozinių ląstelių kiekis statistiškai reikšmingai nepadidejjo. Po 48 val. MCF-7 apoptozinių ląstelių buvo randama ir po 4 ir 6 Gy dozių poveikio, kai MDA-MB-231 linijos reikšmingas apoptozinių ląstelių kiekis nustatytas esant didžiausioms 8 ir 10 Gy dozėms. Po 72 val. apoptozinių MCF-7 ląstelių statistiškai reikšmingai buvo padidejję po visų taikytų radioterapijos dozių, o MDA-MB-231 - tik esant didesnèms 6, 8 ir 10 Gy dozėms (4 pav.). Lygindami abiejų tirtų ląstelių linijų apoptozès intensyvumą matome, kad MCF-7 ląstelèse apoptozè prasidejjo anksčiau ir buvo intensyvesnè, negu MDA-MB-231 ląstelèse. MDA-MB-231 ląstelès reagavo vèliau ir turèjo uždelstą apoptozinį atsaką po radioterapijos poveikio.

\section{Diskusija}

Šiam tyrimui buvo pasirinktos dvi skir- 
tingus krūties vėžio potipius atitinkančios MCF-7 ir MDA-MB-231 ląstelių linijos. MCF-7 yra neagresyvi, neinvazinè ir mažą potencialą metastazuoti turinti ląstelių linija. Šiai linijai būdinga estrogenu ir progesteronų receptorių raiška, todèl ji priskiriama liuminaliniam A krūties vėžio potipiui [15]. MDA-MB-231 linijos ląstelès turi trejopai neigiamam potipiui būdingas charakteristikas. Šios ląstelès nepasižymi nei estrogenų, nei progesteronų, nei HER2 receptorių raiška ir yra labai agresyvi krūties vėžio forma [16]. Siekiant išsiaiškinti minètu ląstelių atsaką ị radioterapiją, buvo atlikti gyvybingumo, ląstelès ciklo ir apoptozès intensyvumo tyrimai.

Pirmiausia lyginome aukščiau aprašytų ląstelių linijų jautrumą radioterapijai. Naudojome kolonijų formavimo testą, kuris yra jonizuojančiosios spinduliuotès poveikio ląstelèms tyrimų in vitro vertinimo auksinis standartas [17]. Gautų rezultatų analizè parode, kad MDA-MB-231 ląstelių linijos išgyvenimas buvo didesnis esant visoms taikytos radioterapijos dozèms, o tai rodo didesnị MDA-MB-231 ląstelių atsparumą radioterapijai, lyginant su MCF-7 ląstelemis. Šie mūsų duomenys sutapo su X. Chen ir kt. atliktų tyrimų rezultatais. Naudodami kolonijų formavimo testą, tyrejai taip pat nustate didesnị MDA-MB-231 ląstelių atsparumą radioterapijai, lyginant su MCF-7 ląstelèmis [18]. Skirtingą šių ląstelių linijų atsparumą jonizuojančiajai spinduliuotei pastebejo ir Q. Zhang su kolegomis, švitindami ląsteles 2, 4 ir 8 Gy dozèmis [19]. Tokị skirtingą ląstelių atsaką ị radioterapiją būtų galima paaiškinti remiantis jų skirtingais potipiais ir būdingoms charakteristikoms, tačiau mokslinėse publikacijose sutinkama ir prieštaringų rezultatų. F. Feng ir kt. tyrimuose su skirtingomis krūties vèžio ląstelių linijomis nenustate reikšmingo skirtumo tarp krūties věžio potipių ir jų atsako ị radioterapiją [20]. Q. Zhang su kolegomis, tirdami metformino ir radioterapijos poveiki, nustate, kad tik radioterapijos poveikyje esant 2, 4 ir 6 Gy dozèms šių ląstelių gyvybingumas reikšmingai nesiskyre [21]. Šie prieštaringi tyrimų rezultatai gali atsirasti dẻl skirtingų gyvybingumo testų metodikų, ląstelių apšvitinimo sąlygų ar naudotų ląstelių kokybès, todèl reikalingi tolesni ir išsamesni tyrimai MDA-MB-231 ląstelių radioatsparumui patvirtinti.

Ląstelių ciklo analizè po jonizuojančiosios spinduliuotès poveikio gali būti vienas iš metodų, nustatant ląstelių radiojautrumą [14], todèl buvo nuspręsta ištirti, ar ląstelių pasiskirstymas tarp ciklo fazių po radioterapijos poveikio skirsis tarp skirtingu radioatsparumu pasižyminčių MCF-7 ir MDA-MB-231 ląstelių. Rezultatai parodè, kad radioterapijai jautresnių MCF-7 ląstelių ciklas galimai buvo sustabdytas G0/G1 fazèje, o didesniu atsparumu pasižymėjusios MDAMB-231 ląstelès - G2/M fazèje. Šis skirtumas gali būti aiškinamas remiantis p53 geno statusu mūsų tiriamose ląstelèse. Literatūros duomenimis, MCF-7 ląstelèse p53 yra normaliai išreikštas [22], o MDA-MB-231 - mutuotas [23]. P53 vadinamas ,genomo sargybiniu“ dèl savo savybės pajusti DNR pažeidi-

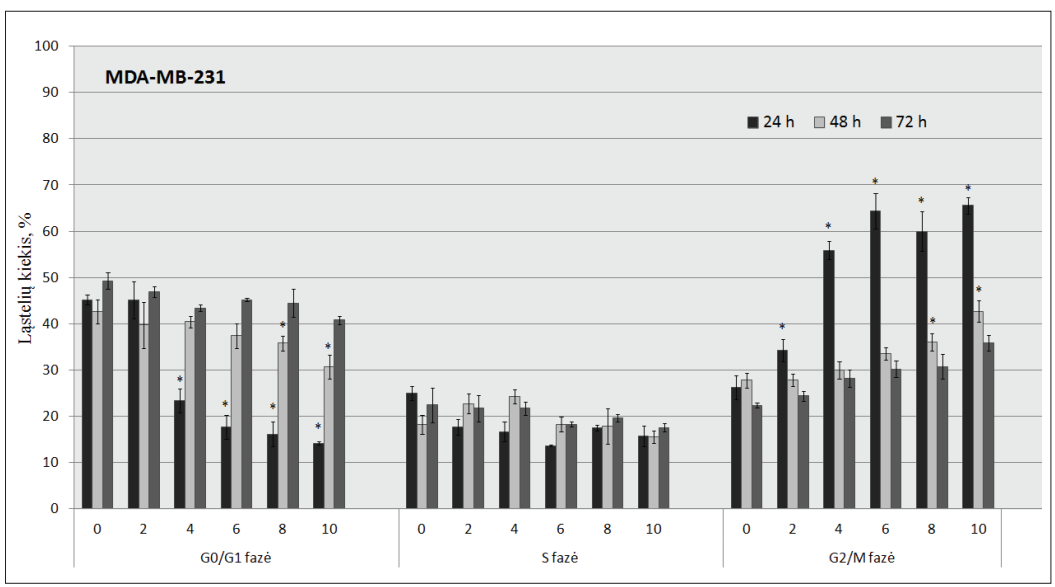

3 pav. MDA-MB-231 ląstelių pasiskirstymas tarp ciklo fazių po 0, 2, 4, 6, 8, 10 Gy dozių radioterapijos poveikio

Kiekvienas taškas yra trijụ nepriklausomu eksperimentụ vidurkis su standartiniu nuokrypiu. Žvaigždutè (*) rodo statistiškai reikšminga vertę, lyginant su kontroline.

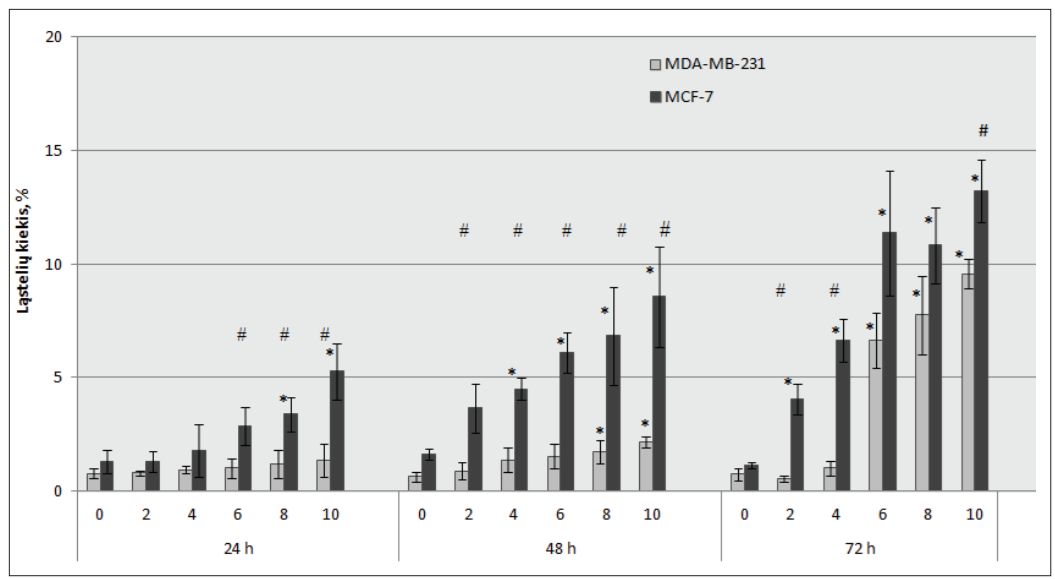

4 pav. MDA-MB-231 ir MCF-7 apoptozinių ląstelių priklausomybė nuo radioterapijos dozių ir laiko

Kiekvienas taškas yra trijų nepriklausomu eksperimentu vidurkis su standartiniu nuokrypiu. Žvaigždutè (*) rodo statistiškai reikšmingą vertę, lyginant su kontroline, grotelès (\#) - statistiškai reikšminga vertę tarp lastelin liniju. 
mus ir skatinti šių pažeidimų ištaisymą. Po jonizuojančiosios spinduliuotés poveikio p53 baltymo kiekis padideja, kaupiasi branduolyje ir sustabdoma baltymo degradacija [24]. Branduolyje veikdamas kaip transkripcijos faktorius, aktyvuotas p53 sukelia ląstelès ciklo sustabdymą G1 fazèje, o ląstelèse su DNR pažeidimais, kurie negali būti ištaisyti, p53 sukelia apoptozę [25]. Kadangi MCF-7 ląstelèse p53 išreikštas normaliai, galima manyti, kad šių ląstelių ciklo sustabdymą G0/G1 fazèje galèjo lemti radioterapijos sukelta p53 aktyvacija. Ląstelès, kuriose p53 yra mutuotas ar įvykusi jo delecija, gali išvengti p53 kontrolès ir ląstelès ciklo sustabdymo G0/G1 fazèje [25]. Tai galètų būti vienas iš paaiškinimų, kodèl MDA-MB-231 ląstelių ciklas po radioterapijos buvo sustabdytas G2/M fazèje, o G0/G1 fazės buvo išvengta. Šiems teiginiams patvirtinti reikalingi išsamesni tyrimai.

MDA-MB-231 ląstelių ciklo sustabdymas G2/M fazèje gali būti siejamas su jų didesniu atsparumu radioterapijai. J. Li ir kt. savo publikacijoje teigia, kad věžinių ląstelių kaupimasis po radioterapijos $\mathrm{G} 2 / \mathrm{M}$ fazèje gali būti vienas iš veiksnių, dalyvaujančiu ịgyjant ląstelių radioatsparumą. Mūsų rezultatai sutapo su šia studija, kurioje buvo nustatyta, kad plaučių vėžio radioatspariose ląstelèse po radioterapijos poveikio praejjus 24 valandoms G2/M fazèje ląstelių kiekis buvo didesnis, lyginant su radiojautriomis ląstelèmis [26]. Panašus tyrimas buvo atliktas ir su mieloidinès leukemijos ląstelèmis, kur M. Hazawa su kolegomis nustaté, kad didejant radioterapijos dozei, ženkliai padidèjo ir radioatsparių ląstelių kiekis G2/M fazèje [27]. Ch. Liu ir kt. savo tyrimais parodè, kad tiriant ląstelès ciklą galima ìvertinti ląstelių atsparumą jonizuojančiajai spinduliuotei pagal susikaupusių ląstelių kiekị G2/M fazèje: kuo daugiau ląstelių G2/M fazeje, tuo didesnis radioatsparumas [14]. Jonizuojančiosios spinduliuotès poveikyje ląstelèse suaktyvinami ciklo kontrolès taškai, kurie leidžia laiku atlikti pažaidų atitaisymą arba negrižtamai sustabdyti ciklą ir inicijuoti ląstelès mirtị. Žinant, kad homologinè rekombinacija vyksta S ir G2 fazèse, G2/M patikros taškai sustabdo ląstelès ciklą ir suteikia pakankamai laiko ląstelių pažaidų atitaisymui [28]. Paprastai visos ląstelès su nedideliais pažeidimais ir efektyvia reparacijos sistema po jonizuojančiosios spinduliuotès poveikio i normalų ciklą grižta po 48 valandų [14]. DNR pažeidimai, kurių nepavyksta ištaisyti per 48 valandas, gali sukelti apoptozinių ląstelių skaičiaus padidejjimą po 72 valandų [28]. Tai glaudžiai siejasi su mūsų gautais MDA-MB-231 ląstelių apoptozès tyrimų rezultatais, kai po 72 valandų 6,8 ir 10 Gy dozių poveikyje buvo reikšmingai padidèjęs apoptozinių ląstelių skaičius.

Lyginant ląstelių apoptozinị atsaką ị radioterapiją, buvo nustatyta, kad MCF-7 ląstelèse apoptozè pasireiškè anksčiau ir buvo intensyvesnè, o MDA-MB-231 ląstelès reagavo vèliau ir apoptozinis atsakas buvo uždelstas. Mūsų duomenys sutapo su Q. Zhang ir kt. gautais tyrimų rezultatais, kurie taip pat parode, kad jonizuojančioji spinduliuotè sukelia didesni apoptozès intensyvumą MCF-7 ląstelèms, negu MDA-MB-231 [19]. Manoma, kad padidejęs ląstelių apoptozinis atsakas ị radioterapiją rodo ląstelių didesnį radiojautrumą, todèl kai kurie mokslininkai apoptozès intensyvumą laiko vienu iš būdų vėžinių ląstelių radiojautrumui nustatyti [29]. Mūsų atlikta apoptozès tyrimo analizè parodè, kad MCF-7 ląstelès buvo jautresnès radioterapijai, negu MDA-MB-231 ir tai sutapo su mūsų gautais ląstelių gyvygingumo rezultatais.

MDA-MB-231 ląstelių radioatsparumas gali būti siejamas su viena iš vėžinėms ląstelèms būdingų savybių - slopinti ar išvengti apoptozès. Literatūroje aprašoma keletas už ląstelių išgyvenamumą atsakingų signalinių kelių, kurie aktyvinami po jonizuojančiosios spinduliuotès poveikio ir gali nuslopinti apoptozę, sumažinti radioterapijos citotoksiškumą bei padidinti vėžio ląstelių išgyvenamumą. Vienas tokių yra ERK1/2 signalinis kelias, kuris ląstelèje po radioterapijos poveikio aktyvinamas ir gali sukelti apoptozès sulaikymą, pagerinant antiapoptozinių baltymų, tokių kaip Bcl-xl, aktyvaciją ir nuslopinant proapoptozinių baltymų aktyvumą [30]. Kitas nemažiau svarbus ląstelių išgyvenamumo veiksnys yra AKT, kuris aktyvintas jonizuojančiosios spinduliuotès, neigiamai paveikia apoptozinius ląstelių kelius, leidžiant véžio ląstelèms išlikti po radioterapijos poveikio. AKT gali veikti per keletą mechanizmų, tokių kaip pro-apoptozinių Bad, Bax, Bim ir Noxa baltymų slopinimas; NF-KB fosforilinimas, sukeliant antiapoptozinių Bcl-2 ir Bcl-xl baltymų raišką; XIAP aktyvacija, dèl kurios slopinamos kaspazės 3, 7, 9; m-TOR kinazès signalinio kelio aktyvacija, kuri kartu sukelia ir antiapoptozinio baltymo MCL-1 aktyvaciją [31]. Jonizuojančioji spinduliuote taip pat aktyvina JAK-STAT signalinį kelią, padidindama JAK-2 ir STAT fosforilinimą. STAT translokacija ị ląstelès branduolị padidina Bcl2/Bcl-xl baltymų kiekị, todèl sumažèja kaspazès-3 aktyvumas. Šie procesai leidžia vėžinei ląstelei išgyventi po radioterapijos ir ịgyti atsparumą [32]. Siekiant išsiaiškinti, kokie molekuliniai mechanizmai sukelia mūsų tiriamų MDAMB-231 ląstelių radioatsparumą, reikia ištirti minètų signalinių kelių svarbiausias signalines molekules ar baltymus ir įvertinti jų reikšmę, slopinant ląstelių apoptozę.

Ištyrę MCF-7 ir MDA-MB-231 ląstelių atsaką ị radioterapiją nustatème, kad šios skirtingiems molekuliniams potipiams priskiriamos ląstelių linijos pasižymi ir skirtingu atsparumu radioterapijai. Tolimesni tyrimai parodè, kad tiek apoptozè, tiek ląstelès ciklas gali būti svarbūs šių ląstelių radioatsparumui. Mūsų atliktų tyrimų patvirtinimui reikalingi išsamesni molekuliniai tyrimai, siekiant išsiaiškinti, kokie signaliniai keliai ar molekulès atsakingi už mūsų tiriamų ląstelių radioatsparumą. Tai padètų nuspèti skirtingų potipių reakcijas ị spindulinę terapiją. Tuomet būtų naudinga sumažinti radiacinę 
dozę pacientams, kurių navikai yra jautresni radioterapijai, kartu sumažètų normalių aplinkinių audinių pažeidimai bei šalutinis jonizuojančiosios spinduliuotès poveikis. Radioterapijai atspariems navikams galètų būti skiriamos papildomos terapinès dozès, siekiant sumažinti naviko atkryčio riziką [33].

\section{Išvados}

1. MDA-MB-231 krūties vèžio ląstelių linija pasižymėjo didesniu atsparumu radioterapijai, negu MCF-7 ląstelès.

2. Ląstelès ciklo analizè parodè, kad MDA-MB-231 ląstelių radioatsparumas gali būti susijęs su G2/M ciklo fazès sulaikymu.

3. Po radioterapijos poveikio MCF-7 ląstelèse apoptozè prasidejo anksčiau ir buvo intensyvesnè, o MDA-MB-231 ląstelès reagavo vèliau ir turèjo uždelstą apoptozinį atsaką.

\section{Literatūra}

1. Sung H, Ferlay J, Siegel RL, Laversanne M, Soerjomataram I, Jemal A, Bray F. Global cancer statistics 2020: GLOBOCAN estimates of incidence and mortality worldwide for 36 cancers in 185 countries. CA Cancer J Clin 2021;0:1-41.

https://doi.org/10.3322/caac.21660

2. Pan XB, Chen RJ, Huang ST, Jiang YM, Zhu XD. Systematic review and meta-analysis of the efficacy of breast conservation therapy followed by radiotherapy in four breast cancer subtypes. Oncotarget 2017;8(34):57414-57420.

https://doi.org/10.18632/oncotarget.18205

3. Xiaofeng Dai, Ting Li, Zhonghu Bai, Yankun Yang, Xiuxia Liu, Jinling Zhan, and Bozhi Shi. Breast cancer intrinsic subtype classification, clinical use and future trends. Am J Cancer Res 2015; 5(10): 2929-2943.

4. Abdel-Hafiz HA. Epigenetic mechanisms of tamoxifen resistance in luminal breast cancer. Diseases 2017;5(3):16.

https://doi.org/10.3390/diseases5030016

5. Horton JK, Siamakpour-Reihani S, Lee CT, Zhou Y, Chen W, Geradts J, Fels DR, Hoang P, Ashcraft KA1, Groth J, Kung HN, Dewhirst MW, Chi JT. FAS death receptor: a breast cancer subtype-specific radiation response biomarker and potential therapeutic target. Radiat Res 2015;184(5):456-69. https://doi.org/10.1667/RR14089.1

6. He L, Lv Y, Song Y, Zhang B. The prognosis comparison of different molecular subtypes of breast tumors after radiotherapy and the intrinsic reasons for their distinct radiosensitivity. Cancer Management and Research 2019;11:5765-5775.

https://doi.org/10.2147/CMAR.S213663

7. Chen X, Ma N, Zhou Z, Wang Z, Hu Q, Luo J1, Mei X, Yang Z, Zhang L, Wang X, Feng Y, Yu X, Ma J, Guo X. Estrogen receptor mediates the radiosensitivity of triple-negative breast cancer cells. Med Sci Monit 2017;23:2674-2683.

https://doi.org/10.12659/MSM.904810

8. Guo Q, Zhu D, Bu X, Wei X, Li C, Gao D, Wei X, Ma
X, Zhao P. Efficient killing of radioresistant breast cancer cells by cytokine-induced killer cells. Tumour Biol 2017;39(3):1010428317695961.

https://doi.org/10.1177/1010428317695961

9. Gray M, Turnbull AK, Ward C, Meehan J, Martínez-Pérez C, Bonello M, Pang LY, Langdon SP, Kunkler IH, Murray A, Argyle D. Development and characterisation of acquired radioresistant breast cancer cell lines. Radiation Oncology 2019;14(1):64. https://doi.org/10.1186/s13014-019-1268-2

10. Pawlik TM, Keyomarsi K. Role of cell cycle in mediating sensitivity to radiotherapy. Int J Radiat Oncol Biol Phys. 2004;59(4):928-42.

https://doi.org/10.1016/j.ijrobp.2004.03.005

11. Olivares-Urbano MA, Griñán-Lisón C, Marchal JA, Núñez MI. CSC Radioresistance: a therapeutic challenge to improve radiotherapy effectiveness in cancer. Review. Cells 2020;9(7):1651. https://doi.org/10.3390/cells9071651

12. Mohammad RM, Muqbil I, Lowe L, Yedjou C, Hsu HY, Lin LT, Siegelin MD, Fimognari C, Kumar NB, Dou QP, Yang H, Samadi AK, Russo GL, Spagnuolo C, Ray SK, Chakrabarti M, Morre JD, Coley HM, Honoki K, Fujii H, Georgakilas AG, Amedei A, Niccolai E, Amin A, Ashraf SS, Helferich WG, Yang X, Boosani CS, Guha G, Bhakta D, Ciriolo MR, Aquilano K, Chen S, Mohammed SI, Keith WN, Bilsland A, Halicka D, Nowsheen S, Azmi AS. Broad targeting of resistance to apoptosis in cancer. Semin Cancer Biol 2015;35 Suppl(0):S78-S103. https://doi.org/10.1016/j.semcancer.2015.03.001

13. Koff JL, Ramachandiran S, Bernal-Mizrachi L. A time to kill: targeting apoptosis in cancer. Int J Mol Sci 2015;16(2):2942-55. https://doi.org/10.3390/ijms16022942

14. Liu Ch, Nie J, Wang R, Mao W. The cell cycle G2/M block is an indicator of cellular radiosensitivity. Dose Response 2019;17(4):1559325819891008.

https://doi.org/10.1177/1559325819891008

15. Comsa S, Cîmpean AM, Raica M. The story of MCF-7 breast cancer cell line: 40 years of experience in research. Anticancer Res 2015;35(6):3147-54.

16. Boo L, Ho WY, Ali NM, Yeap SK, Ky H, Chan KG, Yin WF, Satharasinghe DA, Liew WC, Tan SW, Cheong SK, Ong HK. Phenotypic and microRNA transcriptomic profiling of the MDA-MB-231 spheroid-enriched CSCs with comparison of MCF-7 microRNA profiling dataset. Peer J 2017;5:e3551. https://doi.org/10.7717/peerj.3551

17. Braselmann H, Michna A, Heß J, Unger K. CFAssay: statistical analysis of the colony formation assay. Radiat Oncol 2015;10:223.

https://doi.org/10.1186/s13014-015-0529-y

18. Chen X, Ma N, Zhou Z, Wang Z, Hu Q, Luo J, Mei X, Yang Z, Zhang L, Wang X, Feng Y, Yu X, Ma J, Guo X. Estrogen receptor mediates the radiosensitivity of triple-negative breast cancer cells. Med Sci Monit 2017;23:2674-2683.

https://doi.org/10.12659/MSM.904810 
19. Zhang Q, Kong Y, Yang Z, Liu Y, Liu R, Geng Y, Luo H, Zhang H, Li H, Feng S, Wang X. Preliminary study on radiosensitivity to carbon ions in human breast cancer. J Radiat Res 2020;61(3):399-409.

https://doi.org/10.1093/jrr/rraa017

20. Feng FY, Speers C, Liu M, Jackson WC, Moon D, Rinkinen J, Wilder-Romans K, Jagsi R, Pierce LJ. Targeted radiosensitization with PARP1 inhibition: optimization of therapy and identification of biomarkers of response in breast cancer. Breast Cancer Res Treat 2014;147(1):81-94. https://doi.org/10.1007/s10549-014-3085-5

21. Zhang Y, Storr SJ, Johnson K, Green AR, Rakha EA, Ellis IO, Morgan DA, Martin SG. Involvement of metformin and AMPK in the radioresponse and prognosis of luminal versus basal-like breast cancer treated with radiotherapy. Oncotarget 2014;5(24):12936-49.

https://doi.org/10.18632/oncotarget.2683

22. Leroy B, Girard L, Hollestelle A, Minna JD, Gazdar AF, Soussi T. Analysis of TP53 mutation status in human cancer cell lines: a reassessment. Hum Mutat 2014;35(6):756-65. https://doi.org/10.1002/humu.22556

23. Cleator S, Heller W, Coombes RC. Triple-negative breast cancer: therapeutic options. Lancet Oncol 2007;8(3):235-44. https://doi.org/10.1016/S1470-2045(07)70074-8

24. Mundt AJ, Roeske JC, Chung TD, Weichselbaum RR. Biologic basis of radiation therapy. Holland-Frei Cancer Medicine Hamilton (ON): BC Decker 2003.

25. Hyun SY, Jang YJ. P53 activates G1 checkpoint following DNA damage by doxorubicin during transient mitotic arrest. Oncotarget 2015;6(7):4804-4815. https://doi.org/10.18632/oncotarget.3103

26. Li J, Yang CX, Mei ZJ, Chen J, Zhang SM, Sun SX, Zhou FX, Zhou YF, Xie CH. Involvement of cde25c in cell cycle alteration of a radioresistant lung cancer cell line established with fractionated ionizing radiation. Asian Pac J Cancer Prev 2013;14(10):5725-30. https://doi.org/10.7314/APJCP.2013.14.10.5725

27. Hazawa M, Hosokawa Y, Monzen S, Yoshino H, Kashiwakura I. Regulation of DNA damage response and cell cycle in radiation-resistant HL60 myeloid leukemia cells. Oncol Rep 2012;28(1):55-61. https://doi.org/10.3892/or.2012.1771

28. Zhao H, Zhuang Y, Li R, Liu Y, Mei Z, He Z, Zhou F, Zhou Y. Effects of different doses of $X$ ray irradiation on cell apoptosis, cell cycle, DNA damage repair and glycolysis in HeLa cells. Oncol Lett 2019;17(1):42-54. https://doi.org/10.3892/ol.2018.9566

29. Yang Y, Zhou H, Zhang G, Xiaoying X. Targeting the canonical Wnt/ $\beta$-catenin pathway in cancer radioresistance: updates on the molecular mechanisms. J Cancer Res Ther 2019;15:272-7.

30. Rahmanian N, Hosseinimehr SJ, Khalaj A. The paradox role of caspase cascade in ionizing radiation therapy. J Biomed Sci
2016;23(1):88

https://doi.org/10.1186/s12929-016-0306-8

31. Hein AL, Ouellette MM, Yan Y. Radiation-induced signaling pathways that promote cancer cell survival. Int J Oncol 2014;45(5):1813-9.

https://doi.org/10.3892/ijo.2014.2614

32. Salehifar E, Hosseinimehr SJ. The use of cyclooxygenase-2 inhibitors for improvement of efficacy of radiotherapy in cancers. Drug Discov Today 2016;21(4):654-62.

https://doi.org/10.1016/j.drudis.2016.02.019

33. Horton JK, Siamakpour-Reihani S, Lee CT, Zhou Y, Chen W, Geradts J, Fels DR, Hoang P, Ashcraft KA, Groth J, Kung HN, Dewhirst MW, Chi JT. FAS death receptor: a breast cancer subtype-specific radiation response biomarker and potential therapeutic target. Radiat Res 2015;184(5):456-69.

https://doi.org/10.1667/RR14089.1

EVALUATION OF RESISTANCE DIFFERENT BREAST CANCER CELL LINES TO RADIOTHERAPY

\section{Laukaitienė, A.Vaitkus, A. Savukaitytė, R. Vadeikienė,} R. Ugenskienė, A. Inčiūra, E. Juozaitytė

Keywords: breast cancer, resistance, radiotherapy, apoptosis, cell cycle.

Summary

Introduction. Radiotherapy is one of the major modalities for the treatment of human cancers and is used to treat more than $50 \%$ all cancerous patients. However, a major contributor to radiotherapy failure and unsuccessful treatment is believed to be resistance of cancerous cells to radiation. One of the key features of cancer cell resistance to radiotherapy is their associated avoidance to apoptotic cell death. Accumulated evidence has suggested that cell cycle also may function as a regulatory process in radioresistance. This study aimed to evaluate the resistance of two MDA-MB-231 and MCF-7 breast cancer cell lines to radiation therapy comparing their viability, apoptosis intensity and distribution of cells between phases of the cycle. Methods. The radiosensitivity of MCF-7 and MDAMB-231cells was compared using colony formation assays. Distribution of cell cycle the cells were stained with propidium iodide and were analyzed by flow cytometry the Muse Cell Analyzer system. To detect apoptosis the cells were stained with annexin V and were analyzed using a Guava PCA flow cytometry. Results. Our results suggest that MDA-MB-231 cells had a higher survival rate than MCF-7 cells. A cell cycle analysis has shown that after cells were exposed to irradiation, MDA-MB-231 cells are characterized by the accumulation of cells in $\mathrm{G} 2 / \mathrm{M}$ phase and MCF-7 cell cycle was arrested at the G0/G1 phase. Apoptosis studies have shown that MDA-MB-231 cells exhibit a significantly delayed apoptotic response to ionizing radiation compared to $\mathrm{MCF}-7$ cells. Conclusion. We concluded that the MDA-MB-231 cells were more radioresistant than the MCF-7 cells.

Correspondence to: danguole.laukaitiene@1smuni.lt

Gauta 2021-03-23 